\title{
Doğal Afetler, Toplumsal Değişme ve Dirençlilik İlişkisi: \\ Toplumsalın Yeniden İnşası Üzerine Bir Değerlendirme
}

\section{The Relationship Among Natural Disasters, Social Change and Resilience: An Analysis on Reconstruction of the "Social"}

\author{
F. Gaye GÖKALP YILMAZ
}

(D)0000-0002-6304-3425

\section{MAKALE BILGİSİ}

Bašuru: 14. 07. 2021

Düzeltme Talebi: 16. 07. 2021

Son Düzeltme: 29. 07. 2021

Kabul: 29. 07. 2021

Online Yayım: 15. 08. 2021

\section{Anahtar Kelimeler:}

\section{Sosyoloji}

Sosyal Değişme

Dirençlilik

Kırılganlık

Afet

\section{ARTICLE INFO}

Submitted: 14.07 .2021

Revision Requested: 16.07 .2021

Final Revision Received: 29. 07. 2021

Accepted: 29. 07. 2021

Published Online: 15. 08. 2021

\section{Keywords:}

Sociology

Social Change

Resilience

Vulnerability

Disaster
ÖZ

Bu çalıșmada, sosyolojinin kuruluşundan itibaren en temel çalıșma konularından biri olan değișme kavramının sosyoloji tarihinde ele alınış biçimlerine değinilerek, yirmi birinci yüzyılda afetler ve sonrasında yaşanan değişme süreçleriyle beraber incelenmesi amaçlanmıștır. $\mathrm{Bu}$ amaç doğrultusunda, klasik değișme kuramları kısaca incelenerek, değişmenin temel dinamikleri ortaya konulmuştur. Ardından, yirmi birinci yüzyılda sayıları artan doğal afetler sonrasında yaşanan travma ve yıkım sonucunda gerçekleşen fiziksel ve toplumsal değişimler dirençlilik kavramıyla ele alınarak, değişme ve sosyal değişme ilişkisine değinilmiştir. Afet sonrasında yeniden düzene dönebilme kapasitesi olarak ele alınabilecek olan dirençlilik ile değișme birbiriyle yakın ilişsili olarak tartışılmış ve özellikle dirençliliğin bir alt kategorisi olarak kırılganlık kavramı da sosyal boyutuyla incelemeye dahil edilmiştir. Değişme, dirençlilik ve kırılganlık kavramları ekseninde, toplumların afet sonrası düzene yeniden geri dönebilme veya yeni düzene uyum sağlama kapasiteleri önemli belirleyiciler olarak kabul edilmektedir. Dolayısıyla, afet yönetimi planlarında ve hazırlık aşamalarında, dirençlilik kapasitelerinin belirlenebilmesi, sosyal kırılganlık düzeyleriyle ilişkili olarak önem taşımaktadır. Ayrıca, siyasalar oluşturulurken, dikkate alınacak planlarda, değişme ve dirençlilik ilişkisine önem verilmesi, toplumların en kısa sürede yeniden düzene ve uyumluluğa kavuşabilmesine önemli katkılar sağlayacaktır.

\section{ABSTRACT}

This study aims to analyse the concept of change that has been considered one of the most important aspects of sociology since its appearance as a distinct field of study. Fundamental dynamics of change have been analysed briefly through an analysis of the classical theories on change. Then, the physical and social changes resulting from trauma and destruction after natural disasters are discussed, whose number increased in the twenty-first century. The concept of resilience and the relationship between change and social change is also discussed. Resilience and change are necessary to establish social order. Hence, these two are addressed in addition to the concept of vulnerability which is a sub-category of resilience. In line with the concepts of change, resilience, and vulnerability, the capacity of societies to return to the pre-disaster conditions and order or adaptation to the new order is considered to be important determinants. Therefore, determining the resilience capacities of disaster management procedures is examined concerning social vulnerability levels. In conclusion, it is suggested that the relationship between change and resilience must be carefully considered in the plans by formulating new policies. Such practices will make significant contributions to restoring order and harmony in societies after disasters.

*Yazar İletişim/ Corresponding Author: F. Gaye Gökalp Yılmaz (Dr. Öğr. Üyesi), Burdur Mehmet Akif Ersoy Üniversitesi, Fen Edebiyat Fakültesi, Sosyoloji Bölümü, Burdur, Türkiye $\bowtie$ fgyilmaz@mehmetakif.edu.tr

Kaynak Gösterimi/ Citing This Article: Gökalp-Yılmaz, F.G. (2021). Doğal afetler, toplumsal değişme ve dirençlilik ilişkisi: Toplumsalın yeniden inşası üzerine bir değerlendirme. Sosyolojik Bağlam Dergisi, 2 (2), 119-132. Doi: 10.52108/2757-5942.2.2.8 


\section{Giriş}

"Düzen" ve "devamlılık" toplumun ve toplum bilim çalışmalarının başlangıcından itibaren en yaygın olarak çalışılan kavramlardandır. Sosyolojinin bağımsız bir disiplin olarak ortaya çıkmaya başladığı dönem, olarak kabul edilen Fransız İhtilali sonrası karmaşa dönemi de benzer biçimde Auguste Comte tarafından, eski düzene geri dönmenin yollarının tartışıldığı ve bu tartışmaların toplumbilimin temelini inşa etmeye başladığı dönemler olarak tanımlanmaktadır. Tüm bu düzen tartışmalarının ardında ise değişme gerçeği bulunmaktadır. Toplumlar, değişme ve farklılaşmadan uzak bir biçimde var olamazlar. İnsanın var oluşu gereği yaşantısını devam ettirebilmek için bir başkasına duyduğu gereksinim, sosyal olma gerçeği ve etkileşimlerin doğası gereği hem bireyler hem de toplumların değişme çerçevesinde incelenmesi sosyolojinin temel uğraşılarından biri olmuştur. Bu bağlamda, sosyal değişme kavramı neredeyse tüm toplum çalışmaları için sürekli devam eden bir inceleme alanı olarak önemini korumaktadır.

Ne var ki, tekli bir nedenselliğe indirgenebilecek bir değişme kuramı ya da açıklama düzeyi kısıtlı olarak kabul edilmektedir. Bu nedenle, değişme kuramlarının tek bir açıklama biçimi üzerinde değil, farklı paradigmalara dayalı olarak ele alınması önemlidir ve tekil bir değișme dinamiğinden bahsetmek son derece güçtür. Ancak, üzerinde uzlaşllan noktalar değişmenin doğasını belirlemek için olanaklı yollar sunmaktadır. Toplumsal değişmenin temel belirleyicileri coğrafya, politik yapı ve üretim biçimlerinden, gündelik yaşam alanlarına, gelenek-göreneklerden, iletişim biçimlerine kadar tüm kültürel etkenler olarak tanımlanabilir (Oktik, 2002;17-18). Her bir toplumsal yapının özgün yönetim ve örgütlenme biçimi değişmenin gerçekleşmesinde en önemli etkenlerden biri kabul edilmektedir ve modern toplumsal hayatta siyasal örgütlenmenin gündelik yaşamı ve kültürel yapıları da belirlediği düşünüldügünde bu toplumsal yapı ve değişme arasındaki ilişki ekseninde daha derin inceleme alanlarını beraberinde getirmektedir.

\subsection{Sosyolojide “Değişme” ve Toplumsal Değişme Kuramları}

Sosyolojik düşüncenin bağımsız bir disiplin haline gelme sürecinde özellikle Avrupa'nın deneyimlediği Fransız İhtilali ve Sanayi Devrimi, yine Avrupa'da insanı ve toplumu konu edinen sosyal bilim dallarının da kuram geliştirmede öncü olmaları sonucunu doğurmuştur. Başka bir deyişle, Freyer'in belirttiği gibi 'İnsanda yerleşip kökleșen yeni bir düşünceden başka hiçbir şey yeni bir toplumsal düzeni yaratamaz' (Freyer, 2015:57). Dolayısıyla, Fransız İhtilali sonrası ivme kazanan düşünce akımlarında Auguste Comte ve Saint-Simon, Sanayi Devrimi Sonrası İngiltere'de ise David Ricardo ve Adam Smith gibi öncü düşünürler kuramlarını inşa etmişlerdir.

Fransız Devrimi sonrasının kargaşası içinde yetişen ve döneminin gelenekçi ve reformcu görüssleri içerisinde çalışmalarını ortaya koyan ve sosyolojinin kurucusu kabul edilen Auguste Comte, tüm toplumlar için geçerli bir doğrusal değişme kuramını inşa etmeye çalışmış ve bu anlamda da eleştirilere maruz kalmıştır. Comte sosyolojisinde toplumdaki düzeni ve değişmezliği toplumsal statik ile analiz ederken, değişmeyi, evrim ve ilerlemeyi toplumsal dinamiğin konusu yapmıştır (Kongar, 1995: 94).

Toplumsal dinamik olarak incelediği alanın bir çözümlemesi olarak Comte, toplumsal değişmeyi kuramsallaştırırken, teolojik, metafizik ve pozitivist aşamaları tanımlar. Bu aşamada Comte, insan zihninin geçirdiği merhaleler ile toplumsal değişmenin ilişkisini kurar; İnsan zihninin teolojik merhaleden başlamak üzere metafizik düşünüş merhalesinden geçerek pozitif düşünüş çağına ulaşması 'toplumsal dinamiğin ana yasasını oluşturur' (Freyer, 2015: 56). Comte'a göre, yalnızca iktisadi ve toplumsal hayatta ortaya çıkan değişimlerin toplumsal değişmenin kaynağı olduğunu düşünmek yanlışlıktır ve ona göre, ' İnsanda yerleșip kökleșen yeni bir düşünceden başka hiçbir şey yeni bir toplumsal düzeni yaratamaz' (Freyer, 2015:57). İdealist bir tarih tasavvuru içerisinde Comte üç hal yasası olarak da bilinen bu toplumsal değişme kuramını şu şekilde açıklamaktadır;

“ Teolojik tasavvurlara tutkun bir zihniyet taşlyan insanlar, monoteizme yükseldikten sonra, toplumu mükemmel bir şekilde düzenlemeyi başarmıştır. Bunun örneği Orta Çağ Kilisesi ve 
onun șekillendirdiği Orta Cağ topluluk düzenidir. Pozitif bilim ise, verimsiz iktisadi hürriyet prensibi yerine, serbest olmayan sosyalist üretim tarzını yerleştirecek ve her kişiye toplumsal hiyerarşideki yerini gösterecektir" (Freyer, 2015: 58).

Comte'un burada da belirtilen pozivist ve doğrusal değişme kuramı tüm toplumları açıklayan bir model olduğu için eleştirilse de klasik sosyolojinin temel değişme kuramlarından biri olarak önemini uzun zaman korumuştur. Herbert Spencer'ın toplumu canlı organizma gibi ele alan yaklaşımında ise, giderek gelişen bir organizma olarak toplumlar, karmaşık hale geldikçe birbirlerine olan gereksinimi artmaktadır. Artan gereksinimler ile toplumlar, birbirlerine bağlı olmayan eșitlerden eșit olmayan bağlılıklara doğru evrimsel bir değişme sergilerler. Durkheim bu doğrusal değişme tanımını toplumların mekanik dayanışmadan organik dayanışmaya doğru ilerlemesi olarak tanımlarken, Tönnies bu değişim çizgisini Cemaatten Cemiyete doğru ilerleyen bir süreç olarak açıklar. Karl Marx ise, beşli toplum kategorileştirmesinde, toplumsal yapıyı incelemiş ve ilkel komünal toplumdan sosyalist topluma geçişi değişmenin temel dinamiği olarak kuramsallaştırmıştır. ( Erol, 2008: 127). Tüm toplumlarda benzer süreçlerin yaşanacağına dair varsayımlar toplumlar arası yapısal farklılıkları arka planda bıraktıkları için eleştiriler alsa da, klasik değişme kuramları evrimci ve ilerlemeci tonlardaki çözümlemeleriyle yeni açıklama biçimlerine de her zaman kapı açmıştır.

Kenneth Bock evrimdeki tek biçimlilik adıyla tanımladığı tekli ve evrimci değișme kuramları içerisinde Comte'a vurgu yaparak şu soruyu sorar; "Evrimdeki tek biçimlilik bizi kültürel benzerlikler beklemeye götürmeliyse, o zaman her çağda görülen kültür düzeyindeki farklılıkların çok belirgin genel yelpazesine ne demelidir?" (Bock,2002: 76). Bock, yanıtı ise, Comte'dan başlayarak evrimci ilerlemeci anlayışla üretilen değişme kuramlarında toplumlar arası farklılıkların var olmasının da açıklamasını yine Comte'un karşılaştırmalı yöntem önerisini de ortaya koyarak vermektedir;

"Comte, değişmenin sürekli, normal ve zaman ve mekân bakımından tek biçimli olduğunu, bundan ötürü de, insan toplulukları arasındaki farklilıkların yalnızca rastlantısal müdahalelerin sonucu, niteliğinde geliş̧me derecelerindeki farklılıklar olarak açıklanabildiğini ortaya koyduktan sonra, ancak bütün bunlardan sonra, uygarlığın ilerleyiş̧ini, ilerlemesini, gelișmesini ya da evrimini resmedecek biçimde kültürel farklılıklar yelpazesini tek bir dizi halinde kavramsal olarak düzenleyebilecek bir "karşslaştırmalı yöntem" önerebilecekti... Karşılaştırmalı yöntemi önerebilmek için insanoğlunun tarihinin akışının nasıl olduğuna ilişskin çok genel bir bakışım rehberliğine gereksinim vardı" (Bock, 2002: 76-77).

Bu tarihsel yöntemin özetini yaparken Comte şu net tanımı yapar; "Dönemlerin birbirini izleyişiyle kurulan bağlantılar yerlerin karşılaştırılmasıyla doğrulanabilir" (Comte, 1822: 585). Bu ifade ile döngüsellik vurgulanmakta ve tek biçimlilik açıklamaları yine ön plandaki yerini korumaktadır.

Sosyolojinin kurucu isimleri arasında yer alan Emile Durkheim ve Max Weber, Comte'un ve Spencer'in kuramsallaştırdığı on dokuzuncu yüzyıl evrimci ve tek biçimli ilerlemeci anlayışa dayanan toplumsal değişme kuramlarının aksine, karşılaştırmalı çalışmalarla toplumsal değişmenin çözümlemesini yapmayı amaçlamışlardır. Durkheim yaşadığı on dokuzuncu yüzyıl sonu ve yirminci yüzyıl başlarında, kapitalizmin egemen üretim biçimi haline gelmeye başlamasıyla yaşanan değişimi ve bu değişmenin yarattığ etkileri analiz etmiştir. Durkheim, üretim biçiminde yaşanan farklılaşmanın toplumsal dayanışma, düzen ve farklılık eksenindeki tartışmasını ortaya koyarken, mekanik toplumdan organik topluma doğru değişen toplumsal yapıyı incelemektedir. Benzerliklerin hakim olduğu ve mekanik dayanışmanın tanımlayıcılığıyla açıklanan dönemden, kapitalizmin üretim ilişkileri ve iş bölümü yolu ile kurulan dayanışma dönemine doğru gerçekleşen değişme beraberinde bir çok etkiyi de getirmektedir. Kapitalizmle beraber nüfusun artması, rekabetin ve uzmanlaşma alanlarının artarak belirginleşmesi sonucunda, çatışmanın önüne geçilebilmesi amacıyla toplumsal iş bölümünün gelişmesi organik dayanışmayı tanımlamaktadır. Durkheim, değişmenin temel dinamiği olarak iş bölümünü farklılaşmasını ortaya koyarken bu farklılaşma sürecinde nüfusun da artacağını iddia eder. Nüfusu az olan toplumlarda ise işbölümü de az olacağından farklılıklar da azdır ve homojenlik esastır, gelenekler ve mekanik dayanışma başat 
konumdadır, uzmanlaşma ve işbölümü arttıkça organik dayanışmanın koşulları oluşmaya başlar (Kongar, 1995: 103).

Nüfus ve toplumsal değişme ilișkisini iş bölümü üzerinde birleștiren Durkheim'ın mekanik dayanışmadan organik dayanışmaya doğru tanımladığı değişme yaklaşımı Tönnies'in Cemaat (Gemeinschaft) ve Cemiyet (Gesselschaft) kavramlarında da benzer biçimde esin kaynağı olmuştur.

Max Weber'in toplumları analiz ederken ortaya koyduğu kuram ise, toplumları otoritenin meşrulaştırma biçimine göre sınıflandırmaktadır. Geleneksel, yasal-ussal ve karizmatik otorite tipolojileri, Weber'in toplumların değişme sürecini de betimlemektedir. Bu bağlamda, Weber'in toplumsal değişme anlayışında kültürel ve toplumsal farklılaşma olarak ayrışma yer almaktadır. Weber'e göre;

“ toplumun kültürel değişmesi doğrusal bir yönde gittikçe rasyonelliğe doğru yol almaktadır. Büyüden bilime, çok tanrılıktan tek tanrılı̆̆a geçişler bunun örnekleridir. Bu değişme değerler, inançlar alanında olur. Toplumsal bünye meşruluğunu kaybettiği zaman bir lider çıkar ve eski toplumsal bünyenin yıkıntıları üzerinde izleyicileriyle birlikte yeni bir düzen kurar" (Weber, 1947'den akt. Kongar, 1995: 98).

$\mathrm{Bu}$ düzen kurma beraberinde mutlak bir değişimi de getirmektedir ve akılcılașma ile birlikte bürokratikleşme de ortaya çıkmaktadır. Ayrıca "Protestan Ahlakı" ve "Kapitalizmin Ruhu" arasında, kapitalizmin temel birikim ve üretim ilişkilerinin kurulması için uygun zemini de yaratmaktadır. Dolayısıyla Weberyan değişme kuramında inanç ve fikirlerin gelişmesi ve farklılaşması belirleyici olarak ortaya konulmaktadır.

Sosyolojinin ve felsefenin en önemli isimlerinden Karl Marx'ın toplum kuramı da değișme tartışması üzerine inşa edilmiştir. Özellikle kapitalizmin eleştirisini yaparken Marx'ın diyalektik bir evrim ve değişme modeli ortaya koyduğu iddia edilebilir. Evrimci modellerle benzer biçimde diyalektik yaklaşımda da, evrim sürecinde gerçekleşen her aşamanın aslında kendini tehdit ederek ortadan kaldıracak olan zıddını da yarattığı düşüncesine dayanmaktadır (Kongar, 1995:121). Sıklıkla tez- anti tez ve sentez biçiminde tartışılan diyalektiğin temel ilkesine göre, her varlık kendi zıddını yani anti tezini doğuracaktır. Bu durum, diyalektik modele göre kaçınılmaz kabul edilmektedir. Marksist anlayış da benzer biçimde tarihin içerisinde sınıf çatışmaları temelinde şekillenen analiz ile toplumların birbiri ardına sınıf çatışmalarından geçerek değiştiğini iddia etmektedir. Marx, toplumsal yapının ekonomik üretim ilişkileri, yani altyapı unsurları tarafından belirlendiğini, üretim araçlarının gelişmesi ve daha önce kurulmuş olan düzenle çatışmaya girmesi sonucunda yeni bir düzenin temelinin atılacağını iddia etmektedir. Değişen üretim biçimi yeni bir sınıfı doğuracaktır ve her sınıfın da kendi ideolojisini inşa etmesi kaçınılmazdır. Dolayısıyla, Marx’a göre değişmenin dinamiği, üretim ilişkilerinin kendi diyalektiği içerisinde yeni sınıfsal çatışmaları doğurması ekseninde gerçekleşmektedir. Kölelik, derebeylik, burjuva toplumu ve komünist toplum aşamaları beklenen tarihsel değişme süreçleri olarak Marksist değişme kuramının temelinde yer almaktadır. Evrimci bir anlayışla Marksizmin öngörüsü, analiz ettiği kapitalizmin kendi içerisindeki sınıf çatışmaları sonucunda, komünizme ulaşacağına dayanmaktadır. Bu öngörü kapitalizmin genişleyen ve süre gelen tarihi boyunca sürekli tartışıla gelen bir nokta olmayı sürdürmektedir.

\subsection{Değişme Kuramlarına Eleștiriler ve Farklı Yaklaşımlar}

Toplumsal değişmeye klasik kuramların sunduğu çözümleme biçimleri tek biçimlilikleri, toplumlardaki farklı kültürel yapıları göz ardı ettikleri ya da determinist yapıları nedeniyle eleştirilmiştir. Toplumların özgül yanları ve somut tarihsel farklılıkları da dikkate alarak farklı çözümleme alternatiflerinin ortaya konulması gerekli olduğuna dair tartışmalar özellikle Amerikan Sosyolojisinde yeni kuramsal tartışmaların gelişmesine zemin hazırlamıştır. Bu bağlamda Grand Theory olarak tanımlanan büyük boy kuramlar yerine orta boy kuramların geliştirilmesi ön plana çıkmıştır. Bu bağlamda, demografik değişmeler, kentleşme ve göç dinamikleri, toplumsal hareketler, tabakalaşma gibi konular orta boy kuramların temel odak noktalarını oluşturmuştur. 
Talcott Parsons, Genel Sistem Kuramı adıyla bilinen ve yapısal işlevsel çözümleme modeli biçiminde kurguladığı çalışmalarında üç farklı sistemin toplumu tanımladığını iddia etmektedir ve kişilik sistemleri, toplumsal sistemler ve kültürel sistemler olarak tanımladığı bu sistemler dört işlevsel gerekliliği sağlamaktadır; Uyum, Amaca Ulaşma, Bütünleşme ve Gizillik ya da Kalıp Koruma.

Parsons düzen ve devamlılık vurgusuyla yapısal işlevselciliğin etkisinde toplumsal yapıyı analiz etmiştir. Bu bakış açısına göre eylemler rast gele gerçekleşmezler belirli kalıplaşmış davranış örüntüleri çerçevesinde sergilenirler. Bu davranış örüntüleri de toplumsal aktörlerin eylemlerinin belirlenmesinde toplumsal kurumların etkili olduğu düşüncesine dayanmaktadır. Dolayısıyla, toplumda arzu edilen, kabul edilebilir olan veya olmayan eylemler ve ilişkiler tanımlanmış olmaktadır. Bu tanımlanma ise aile, din, ekonomi gibi toplumsal kurumlar aracılığıyla gerçekleşir ve bu kurumlar aracılı̆̆ıla bireylerin toplumsal statülerinin gerektirdiği rollerin gerekliliklerinin yerine getirilmesi sağlanır. Parsons'un bu şekilde çözümlediği sistem kuramında, sistemler düzene ve parçaların birbirine bağımlılığı özelliğine sahip kabul edilirler ve sistemler kendini sürdürmeye ve dengeye yönelme eğilimindedirler ve sistemler parçaların bütünle ilişkilerini sürdürmeyi, çevresel değişikliklerin denetlenmesini ve sistemin kendi içinde değişme eğilimlerini denetlemesini içeren kendini sürdürmeye yönelirler (Ritzer,2010: 471). Parsons'un "kendi kendisini dengeleyen sistem" yaklaşımında her bir toplumsal öğenin düzenin devamlılığı için işlev gördüğü öngörüsüne dayalı olarak uyum ve bütünleşme gerçekleştiği ortaya konulmaktadır. Bu durumda, her durumda dengeye ve düzene meyilli olan toplumlarda değişmenin mümkün olabilmesinin yolu "işlevlerin evrimsel farklılaşması" yoluyla gerçekleşebilir ve kökten değişmeler, toplumun dışından gelen kavramlaştırıp araştırılmayan bir dış etken olarak alınmak zorunda kalınır (Guessous, More ve Cook, 1967'den akt. Akşit, 1985:215). Ayrıca, sistemin sürekli dengeye ve düzene eğilimli olması iddiasına karşıt olarak sistemin işlevsiz öğelerinin olabileceğini tartışan Merton ve Moore, sistemde dışarıdan gelebilecek gerilimlere, etkilere, normlar arası uyumsuzluklara ve bunların yaratacağı değişmeye değinmektedirler (Moore, 1974:1-22).

On dokuzuncu yüzyılda hakim olan evrimsel ve düz çizgisel olarak tanımlanabilecek değişme kuramlarına karşı yapısal işlevselciliğin önermeleri de eleştirel karşılanmış ve yine büyük bir sistem teorisi yaratma çabasında toplumsal farklllıklar ve özgünlüklere dair tartışmalar süre gelmiştir. Bu bağlamda Childe (1951 ve 1964) ve White (1949) tarafından genel evrim ve Steward (1959) tarafından düz çizgisel evrime karşı çok çizgisel evrim kavramları geliştirilmiştir. Steward'a göre, toplumların tarihleri vardır, bunlar karşılaştırılabilir ve bu karşılaştırmadan bazı evrim çizgileri çlkar, tek, düz çizgisel ve evrensel bir evrim çizgisi yoktur (Akşit, 1985: 217).

Yirminci yüzyılın ortalarında ise pozitivizmin egemen ve mutlak dilinden uzaklaşılması, Lukacs(1971) , Marcuse (1941) ve Gramsci (1976) gibi düşünürlerin tarihçi diyalektik yorumlamaları ve toplumsal değişmenin siyasal dönüşüm boyutunun da tartışmaya dahil edilmesiyle, değişme kuramları artık, değişimin dinamiği olarak sınıfsal hareketliliklere ve özellikle işçi sınıfının değişime katalizör olabilecek konumuna ağırlık vermektedirler. Dolayısıyla, bu yaklaşım tarzında üretim ilişkileri ve ekonomik belirlenimcilik ve maddecilik ön plana çıkmaktadır. Althusser (1971) Marksizmin temel önermelerinden hareketle, bir ekonomik temelin (üretim tarzl, üretim araçları vs)., politik ve hukuki yapıdan oluşan bir üst yapının (devlet ve hukuk sistemi ) ve bir ideolojik yapının (kilise, siyasal inançlar vs) var olduğunu ve üst yapının kapitalizmin varlığı için gerekli koşulları oluşturmaya devam edecek yeniden üretimini sağladığını iddia etmektedir (Althusser, 1971: 137). Yapısalcı yaklaşıma göre, toplumsal değişme "bir üretim biçiminin çeşitli toplumsal kuruluşlara eklemlenerek yeniden üretilmesi ve bu çerçeve içinde hem bu üretim biçiminin gelişmesinin dönemleştirilmesi, hem de farklı toplumsal kuruluşların değişmelerinin dönemleştirilmesi"dir (Oktik, 2006:7).

Jürgen Habermas ise Kamusal Alanın Yapısal Dönüşümü başlıklı çalışmasında, on sekizinci yüzyılda kafelere odaklanarak bu mekânların kamusal alanın oluşmasında merkezi bir rolü olduğunu iddia etmekte ve bu alanların iletişim ve siyasal ve sosyal konuların tartışılması ve fikir üretilmesi için önemini ortaya koymaktadır. Bu görüșe göre, kapitalizmin yükselişiyle birlikte burjuva birliği 
olarak tanımlanan bir sınıfın çıkarı için kamusal alan işgal edilmiştir ve kitle iletişim araçlarının etkisi ve siyasetin geniş toplumsal hayattan kurumsal farklılaşması nedeniyle, çağdaş döneme geçişle birlikte kamusal alan tamamen ortadan kaybolmuştur (Smith, 2005: 73). Habermas sistem dünyası( devlet, kapitalizm ve büyük bürokratik örgütlenmeler) ve yaşam dünyası (dayanışma, yüz yüze iletişim, aile, topluluk ve temel değere bağlılık) kavramlarını da Lukacs'ın orijinal versiyonundan farklı olarak geliştirmiştir ve kamusal alanın yok edildiği, bürokrasinin büyüdüğü, demokrasilerin erozyona uğrayıp, eşitsizliğin artmasını ve iletişimcilerin yerini pasif işçilerin, vergi yükümlülerinin ve tüketicilerin aldığı bir değişimi tanımlar ve sistem dünyasının araçları olan para ve iktidarın egemen hale geldiğini ve iletişimsel rasyonaliteyi engellediğini iddia etmektedir ve çözüm olarak da iletişimsel rasyonaliteyi ve açık, dürüst, bağımsız tartışmayı savunmaktadır (Smith, 2005: 76).

Buraya kadar sunulan kuramlar ve düşünürler ekseninde toplumsal değişmenin farklı ele alınışları ve kavrayışları olduğu ortaya konulmaya çalışılmıştır. Vurgulanması gereken nokta, değişmenin tekil ve tüm toplumları açıklamaya uygun bir modelle ele alınmasının özellikle çağdaș toplumlar açısından mümkün olmamasıdır. Ekonomik ve teknolojik gelişmeler ve kapitalist sistemde büyük ivme kazanan sermaye, bilgi, insan ve meta dolaşımın değişme açısından son derece güçlü belirleyiciler haline geldiği dikkate alınacak olursa, tek biçimli ve kendisi değişmeye açık olamayan kuramların çağdaş toplumların farklılaşma ve değişme sürecini açıllamada yetersiz olacağı iddia edilebilir. Bu noktada, mühendislik, psikoloji, malzeme bilimi ve kentsel planlama alanlarında sıklıkla kullanılan ancak sosyal bilimler açısından ise afet çalışmaları literatüründe daha sık çalışılan bir kavram olan "dirençlilik" kavramına değinmek, afetlerin sıklıkla deneyimlendiği yirmi birinci yüzyıl çağdaş toplumsal değişme yazınına katkı sağlayacaktır.

\section{Dirençlilik Kavramına Kuramsal Yaklaşımlar}

Dirençlilik (resilience / rezilyans) kavramı 17. Yüzyılda Francis Bacon tarafından geliştirilen bir kavramdır ve temel olarak nesnenin bazı basınç biçimlerinin ardından orijinal durumuna geri dönme özelliklerini tarif etmektedir (Lewis, 2020: 3). Ayrıca, dirençlilik kavramı, tehlike ve risk kavramlarıyla ilişskili olarak da incelenmektedir. Bu bağlamda, dirençlilik, yaşanılan herhangi bir travma ya da riske maruz kalınma sonrasında, toplumun kendi risk yönetim planı dahilinde sistem olarak işlevlerini yerine geri getirebilmesini sağlamak adına gerçekleşen afet/risk/ travma ya da şokun etkilerini soğurma, iyileştirme süreçlerine uyum sağlama ve "düzen"li olarak tanımlanabilecek eskiye dönüşü gerçekleştirirken bir yandan da iyileşebilme kapasitesidir. $\mathrm{Bu}$ tanımda yer alan tehlikelere maruz kalma durumu, özellikle yirmi birinci yüzyılda toplumların sıklıkla karşı karşıya kaldıkları afetler sonucunda yaşanan iyileşme dönemlerini de içeren biçimde yeniden ve sıklıkla ele alınmaya başlanan bir durumdur.

Alexander, dirençlilik kavramının, Latince geri tepme ya da rezonans olan tanımından başlayarak, farklı zamanlarda ve farklı disiplinlerdeki etimolojik seyrini aktarmaktadır;

"Retorikte ve edebiyatta dayanıllllk, kendi seviyesini bulmakta özgür olan bir kavram iken, mekanikte malzemelerin doğuştan gelen karakteristik bir özelliğidir. Temelde deneysel olarak belirlenir ve ekolojik sistemlerde dayanıklılık ve dayanıklılığın nasıl korunduğuyla ilgiliyken sosyal sistemlerde daha karışık ve dağınık bir kavramdır "(Alexander, 2013: 2713-2714).

Dirençlilik kavramı doğa bilimlerinde bir nesnenin eski halini alabilmesine dair esneklik ve geri dönüş kapasitesine tekabül ederken, sosyal bilimlerde ise toplulukların yaşadıkları afetler gibi büyük ve travmatik olaylar sonrasında yeniden eski düzene dönebilme başarısı olarak kavramsallaştırılmaktadır. "'Dirençlilik" / "Resilience" bir sosyal sistemin, yaşadığı felaketlerden ders çlkarabilmesi ve gelecekte kendini koruyabilmesi için gerekli kapasiteyi oluşturabilmesini ifade etmektedir. Sistemin kapasitesi, beklenmedik olaylardan başarıly çlkabilmek için kullanılabilecek tüm kaynak ve yeteneklerdir" (Ponamorov ve Holcomb, 2009, s. 131'den akt. Börekçi ve Gerçek, 2018: 43). Burada tanımlanan kaynak ve yeteneklerin göstergeleri üzerine, 
dirençlilik çalışan disiplinlerde tam bir uzlaşı olmasa da üzerinde fikir birliği olan temel göstergeler olarak,

- $\quad$ Doğal/teknolojik bir tehlikeyle karşı karşıya kalan belirli bir yerleşimin hasar aralığı

- $\quad$ Bir felaketin hemen ardından hizmetlerin/acil durumların işleyiş̧ oranı

- $\quad$ Iyileşme süresinin uzunluğu

- Dışyardımın (ulusal/uluslararası) toparlanmaya oranı

- $\quad$ Afet sonrası rehabilitasyon/azaltma sürecinin verimliliği tanımlanmaktadır (Kundak, 2017:60).

Dirençlilik kavramının özellikle fen ve mühendislik ve sonrasında ise kent çalışmalarında kullanılmaya başlamasıyla birlikte kavram yaygınlaşmaya ve farklı disiplinlerin araştırma konularında inceleme alanını oluşturmaya başlamıştır. Artan kullanma bağlı olarak Börekçi ve Gerçek dirençlilik/resilience kavramının sosyal bilimlerde Türkçe kullanım biçimlerini incelemiş ve farklı tanımlamaları ortaya koymuştur. Sosyal bilimler alanında Timmerman'ın kavramı (1981, s.20'den akt. Börekçi ve Gerçek, 2018) ilk kez sosyal bilimler yazınında kullanmıştır. Toplumsal sistem bağlamında dirençlilik; bir toplumsal sistemin ya da öğesinin herhangi bir tehdit, afet ya da travma sonrasında hayatta kalma becerisinin bir ölçütü olarak tanımlarken, esneklik, değişime ayak uydurma, ani gelişen olaylar karşısında geri dönebilme ya da uyum sağlayarak sürdürülebilir olma yeteneği gibi farklı boyutlar da dirençlilik kavramının alt kapsamında ele alınabilmektedir. Sosyal bilimler açısından özellikle uyum ve adaptasyon kavramlarıyla sosyolojinin da önemli bir çalışma konusu olması nedeniyle Dirençlilik kavramı sosyal bilimlerde daha fazla ele alınır duruma gelmiştir. Bu bağlamda, dirençliliğin dönüşüm, değişim, yenilenme ve sürdürülebilirlik boyutları da sosyolojik açıdan önem taşımaktadır. Ayrıca, uyumluluk kavramı dışarıdaki gerekliliklerin tümünü yerine getirerek, uyum sağlayabilmeyi ve yeni bir biçimde uyumla var olabilmeyi tanımlaması açısından, özellikle büyük fiziksel değişimler sonrası toplumların yeniden inşa süreçlerine önemli katkı sağlamaktadır.

Dirençlilikle ilgili fen bilimleri ve mühendislik alanlarında yer alan ve daha sonrasında kent çalışmaları, psikoloji ve örgüt çalışmalarında yaygınlaşmaya başlayan kullanım alanları, afet çalışmalarının da sosyal bilimlerin daha fazla konusu olmaya başlamasıyla, sosyoloji ve sosyal psikoloji alanlarındaki kullanımı da artmaktadır. Bu çalışma da bu bağlamda, sosyoloji literatürünün temel çalışma alanlarından olan değişme kavramının dirençlilik kavramıyla olan ilişkisine kuramsal açıdan değinmeyi amaçlamaktadır.

Değişme kavramının, özellikle düzen ve uyum kavramlarıyla birlikte tartışıla gelen kuramsal tarihinde, Aguste Comte'un sosyolojisi ve temelde Fransız İhtilali sonrasında yaşanan kaotik dönem dikkate alındığında, değişme yazınında "eski düzene dönme" tartışmalarının egemen konumu dikkat çekmektedir. Sosyoloji yazını on sekizinci yüzyıldan yirminci yüzyıla kadar yoğun bir biçimde toplumsal değişmenin kuramsal açıklamalarının yapılmasına odaklanmıştır. Bu çalışmanın önceki bölümlerinde değinilen sosyal bilimciler de benzer biçimde evrim, ilerleme ve değişim kuramları oluşturmaya çalışarak, eski düzene geri dönebilmenin, farklılaşmanın ya da yeni düzene uyum sağlamanın kavramsal ve kuramsal boyutlarını açıklamayı amaçlamışlardır.

\subsection{Afetler Sonrası Sosyal Değişme ve Dirençlilik}

Yirmi birinci yüzyılda ise sosyal bilimler daha fazla disiplinler arası konuya eğilerek, değişmenin yanına, farklı boyutların da eklemlenmesiyle, yalnızca sosyal olan değişmenin değil, fiziksel olan değişmenin de toplumsal alanda yarattığı farklılaşma ve etkilerin incelenmesini konu edinmeye başlamıştır. Kent çalışmaları özelinde, mimari ve planlamanın, afetler ve beraberindeki fiziksel değişmenin toplumsal boyutu önemli bir çalışma alanı haline gelmektedir. Örneğin, artan insan hareketliliği bağlamında göç kuramları artık kent planlarıyla da ele alınır olmuştur, ya da jeolojik değişimlerin insanlar üzerindeki sosyal etkilerinin incelenmesi afet yazınının sosyolojik boyutunun ön plana çıkmasını sağlamıştır.1920 yılında yayınlanan Samuel Prince'in Felaket ve Sosyal Değişme, 
Halifax Afeti Üzerine Sosyal Bir Çalışma başlıklı çalışmasında, Halifax Limanında iki geminin çarpışması sonucu gerçekleşen patlamanın yarattı̆̆ı etki ve toplumsal farklılaşmayı incelenmektedir ve bu çalışma afet sosyolojisinin ilk çalışması olarak literatürde yer almaktadır. Ayrıca, Pitirim Sorokin de 1942 tarihli Afette İnsan ve Toplum: Savas,, Devrimi Kitlık ve Salgının İnsan Zihni, Davranışı, Sosyal Organizasyonu ve Kültürel Hayatı Üzerindeki Etkileri isimli çalışmasında afet kavramına devrim, kıtlık, salgın gibi farklı boyutlardan bakmakta ve afet ve toplum ilişkisine dair önemli çıkarımlar sunmaktadır. Özellikle İkinci Dünya Savaşı sonrası dönemde afet sosyolojisi çalışmalarında Amerikalı bilim insanlarının ağırlığı dikkat çekmektedir. 1960 ve 1970'li yıllarda afet sosyolojisi yazını, afetlerde örgütsel işleyişi daha saha çalışmalarına odaklanırken, 1963 yılıdna Ohio Eyalet Üniversitesi Afet Araştırma Merkezi'nin kurulmasıyla hız kazanmıș ve E. L. Quarantelli (1972) ve R. Dynes'tan (1988) oluşan ekip afet sosyolojisi yazınına önemli katkılar sağlamıştır (Can, 2020: 23).

Afet kavramı, farklı birçok biçimde tanımlanan bir kavramdır. Afetlere ilişkin tanımlar ilgili disiplinlerin yaklaşımları ve nitelikleriyle farklılaşabilmektedir. Mühendislik ve doğa bilimleri açısından tanımlamalar daha çok afetin fiziksel boyutuna odaklanırken, sosyal bilimler alanında, özellikle afet sonrası dönemde ortaya çıkan sonuçlar açısından farklı bir kavrayış ön plana çıkmaktadır. Sosyal bilimler açısından afetler toplumda yarattıkları etkiler açısından büyük değişimler arasında kabul edilen durumlardandır.

"Afeti insanlı̆̆ın sosyo-ekonomik ve sosyo-kültürel etkilerini kesintiye uğratarak büyük can ve mal kayıplarına mal kayıplarına neden olan, eko sistemlerde onarılması uzun yıllar gerektiren çok büyük yıkımlara ve hatta yok oluşlara neden olan genellikle hızlı gelişen bir doğa olayıdır." (Koç vd.'den akt. Gökçen, 2020: 42). Bu tanımlamada özellikle afetlerin doğada yarattığı fiziksel yıkım ön plana çıkarken, kimi tanımlar ise afet sonrası yaşanan yıkımın toplumsal hayatın kesintiye uğraması üzerine odaklanmaktadır. Örneğin; Akyel'e göre; “Bir olayın afet olarak tanımlanabilmesi için insan topluluklarının yaşadıkları ve yerleşim yerleri üzerinde kayıplar meydana getirmesi ve insan faaliyetlerini durdurarak ya da kesintiye uğratarak bir ya da birden fazla yerleşim birimini etkilemesi gerekmektedir". (Akyel, 2007'den akt. Gökçen, 2020: 42).

Tanımlarda da vurgulandığı üzere, afetlerin yarattı̆̆ değişme de düzenin ve rutinin bozulması anlamında önemli bir araştırma alanı olarak ortaya çıkmaktadır. Travmatik ve ani değişimler sonrası toplumsal yapıda meydana gelen farklılaşma, afet sonrası dönemde sergilenen toplumsal davranış, bireysel ve toplumsal iyileşme ve mücadele durumu gibi kavramlar ele alındığında, afet sonrası dirençlilik kavramıyla olan ilişki önem kazanmaktadır.

\begin{abstract}
"Afet; insan topluluklarını yaşadıkları yerlerde aniden veya zamanla gerçekleșen gerek doğanın olağan devinimiyle, gerekse de insanın doğrudan ya da dolaylı müdahalesiyle gerçekleșe; fiziksel, ekonomik, psikolojik ve daha birçok yönden büyük hasarlara ve kayıplara neden olan ve etkileri bakımından önemli toplumsal sonuçlar doğuran sosyal bir olgudur" (Can, 2020: 20).
\end{abstract}

Bu toplumsal etkiler, ekonomi, din, aile gibi toplumsal kurumlarda gerçekleşen önemli değişimler ile birlikte ciddi yapısal değişimlere de neden olabilir. Bu değişimleri tartışan Bates ve Peacok'a göre; "Afetler farklı sosyo-ekonomik ve etnik grupları ve hatta toplumun farklı iş bölümü tabakalarını farklı biçimde etkiler ve sonuç olarak toplumsal tabakalaşma sistemi süreçten etkilenir ve sosyal yapının farklı kısımlarında farklı gerileme ya da ilerleme ortaya çıkabilir" (Bates ve Peacok, 1987 :311-313). Ayrıca yalnızca sosyal sistemdeki değişim değil, değişimin beraberinde getirdiği baskı sonucu uyumun da bir stres yaratması durumu afet sonrası dönemin önemli toplumsal etkilerinden biridir.

"Afetler sosyal sistemin yapısını strese sokarak, mevcut işlevlerini yerine getirip getirmediğini kontrol eder. Dahası, sistem uyum sağlamaya zorlanır ve en azından geçici olarak bu strese ve bu strese neden olan koşullara uyum sağlamaya zorlanır ve bu geçici olan uyum süreci zaman içerisinde sosyal yapıda kalıcı değişimlere neden olabilir ya da ilişkili değişimler yaratabilir (Bates ve Peacok, 1987 :311-313). 
Özellikle afet sonrası dönemde dezavantajlı grupların fırsat eşitsizliklerine daha fazla maruz kalması dirençlilik kapasitesinin kırılganlık kavramıyla ele alınmasını gerekli kılmaktadır. Söz konusu, dezavantajlılık durumu, kadınlar, engelliler, din, dil ve ırk, milliyet, sosyal sınıf ve gelir düzeyi bakımından fırsat eşitsizliklerine maruz kalan dezavantajlı grupların afetlerden sosyal, fiziksel, ekonomik ve duygusal yönden daha fazla etkilendiklerini ve toplumsal rollerini gerçekleştirmelerinde önemli problemler yaşadıklarını ortaya koymaktadır (Enarson vd. 2007'den akt. Can, 2020: 31). Dezavantajlılık dirençlilik kapasitesini olumsuz yönde etkilerken, artan ve derinleșen eşitsizlikler de, afet sonrası iyileştirme ve yeniden inşa süreçlerinde kesintiler ortaya çıkmasına neden olmaktadır ve bu durum da "düzen ve uyum"un gerçekleşmesini güçleştirmektedir. Dolayısıyla, herhangi bir fiziksel ya da buna bağlı toplumsal değişim sonrası hedeflenen, bir an önce "eskiye" ve "normale" dönebilmek ve travmatik değişimin etkilerini en kısa sürede ortadan kaldırmaktır. Bu çalışmanın temel amacına paralel biçimde, dirençlilik kavramının özellikle afet sonrası toplumsal değişme boyutunda önemli bir belirleyici olması altı çizilmesi gereken bir noktadır.

Afet çalışmalarının odak noktasını oluşturan afet yönetiminin dört temel aşaması vardır; Risk ve Zarar Azaltma, Hazırlık, Müdahale ve İyileştirme. Bu dört aşamadan sonrasında ise, yeniden inşa süreci ön plana çıkmakta ve bu aşamada toplumları dirençlilik düzeyi yeniden inşa veya "eski düzene dönüş"ü mümkün kılmaktadır. Yeniden inşa sürecini bir yeniden yapılandırma süreci olarak ortaya koyabilmek de mümkündür.

\begin{abstract}
"Bu yeniden yapılandırma sürecinde zarar gören altyapının inşası, kesintiye uğrayan sağlık, eğitim hizmetlerinin ve sosyal yaşamın normale dönmesi gibi faaliyetler gerçekleștirilmektedir. Aynı zamanda afetzedelere yönelik psiko-sosyal uygulamalar da iyileștirme süreci kapsamındadır. Örneğin kaybolan aile ve komşuluk ilişkilerinin canlandırllması, afet sebebiyle göç etmek zorunda kalanların yeni yerlerine uyumu da iyileștirme aşamasında düşünülmektedir. Bu hizmetler gerçekleștirilmezse afetzedelerin mağduriyetleri artacaktır" (Yaman ve Çakır, 2020: 19-21).
\end{abstract}

Afet sonrası fiziksel, psikolojik ya da sosyal açıdan zarar gören bireylerin, iyileştirme çalışmaları sonucunda eskiye dönüşleri ya da mağduriyet alanlarının ortadan kaldırılması her zaman aynı ve etkili sonucu vermeyebilmektedir. Burada bu çalışmanın da temel inceleme konusu olan dirençlilik yani, toplumun değişen koşullara uyum ve en kısa sürede "eski düzene" dönebilme becerisi ön plana çlkmaktadır.

Dirençliliğin olumsuz bir olayın sonrasında, toplumsal yapının fonksiyonlarını bozulmadan yerine getirebilme, sorunların ve önceliklerin tanımlanması, kaynakların verimli kullanımı ve sistemin önceliklerine uygun amaç ve hedeflere erişilebilmesi açısından belirleyiciliği son derece önemlidir. Özer'e göre, dirençlilik güvenlik risklerini reaktif biçimde azaltmaya odaklanırken, 2000 sonrasında şokların etkisini azaltma, iş dünyası, toplum ve devletlerin şokların etkilerini azaltma becerileri ve önleyici tedbirlerle birlikte ele alınmaya başlamıștır (Özer, 2018: 14). Kamu yönetiminde kötü durumdan kurtulabilme anlayışına odaklanan yeni kavrayıș biçimleri olsa da, özellikle afet sonrası iyileştirme bağlamında ele alınan dirençlilik kavramı, sosyal değişme ve toplum bilim tartışmalarına önemli kuramsal katkılar sunabilmektedir.

Kuramsal olarak; üç alt boyutla ele alınan dirençlilik kavramının birinci boyutu emici (şoklara maruziyetin azaltılması ve şokların etkisinden çabuk kurtulabilmek), uyarlanabilir (değișen koşullara bağlı olarak yeni yaşam alanları konusundaki kapasite) ve dönüștürücü (dirençliliği uzatabilmek için kapasite oluşturmak) olarak tanımlanmaktadır (Özer, 2018: 15). Burada belirtilen bu üç boyuta dair kapasitenin gelişmesi ise özellikle gıda güvenliği, sosyal sermaye, beșerî sermaye, güvenlik, pazara ve hizmetlere ulaşım, kadının konumu, yönetişim vb. birçok unsura yönelik olumsuz etkileri azaltacağı düşünülmektedir. (Smith ve Frankenberger, 2018: 358-359'dan akt. Özer, 2018: 15). Örneğin, Smith ve Frankenberg'in (2018) 2014 yılında Bangladeş'te yaşanan muson yağmurlarına bağlı sel felaketleri sonrasında hanelerin dirençliliği ve gıda güvenliği 
çalışmasında, ailelerin sosyoekonomik gelir düzeyinin de kısa sürede yaşamsal gıda ihtiyacının karşılanabilmesine olanak sağlayacak dirençlilik kapasitesini belirlediği vurgulanmaktadır.

\begin{abstract}
"Dirençliliğin aşamalarında, afet sonrası yeniden yapılanma süreçlerinin öncelikle dengeden başlayan bir normal durumdan, afet, şok ya da travma sonrası yaşanan kaotik sürece geçiş ilk aşamayı oluștururken, dirençliliğin ikinci așaması, etkilenen taraflar ve toplum tarafindan yapılan düzenleme ve müdahaleler değişikliklere uyum sağlamaya başlama aşaması olarak kabul edilirken, değişim devam ettiğinden dengenin üçüncü așama, düzenlemelerin yapılmasıla yeni bir dengeye ulaşılması ve etkilenen tarafların değişime uyum sağlaması olarak tanımlanmaktadır" (Özer, 2018: 18).
\end{abstract}

Uyum aşaması gündelik hayatın ya yeniden "düzen"e dönmeye başladığı aşamayı ya da yeni bir düzen yaratılarak yeni bir düzene geçişe odaklanmaktadır. Bu da sosyolojik açıdan değişmenin en açık kavranabildiği noktayı ortaya koymakta ve klasik değişme kuramlarında da yer alan "düzene geri dönme" sorunsalının varlığını ortaya koymaktadır.

\title{
2. 2 Dirençlilik ve Kırılganlık İlişkisi
}

Eski düzene dönmek ya da yeniden başka bir düzen yaratmak için dirençliliğin yanında kırılganlık kavramı da belirleyici olabilmektedir. Bu iki kavram birbirleriyle ters orantılı bir ilişki içerisinde daha net kavranabilir. "Kırılganlık; bireyin, topluluğun veya sistemlerin tehlikelerin etkilerine duyarlılı̆̆ını, hassasiyetini arttıran fiziksel, sosyal, ekonomik veya çevresel faktörlerdir" (Varol ve Kırıkkaya, 2017: 2). Kırılganlığın yüksek olması dirençliliğin az olmasını ve buna bağlı olarak da, afet sonrasında ya da herhangi bir travma ve şok sonrasında düzene ve uyuma geri dönebilme durumunun güçlüğünü beraberinde getirir. Her ne kadar toplumlar arası farkllıklar temelinde dikkate alınması gerekli olsa da, kırılganlık süreçlerine dair temel olgular, gruplar ve boyutlar şu şekilde tanımlanabilir; yoksullar, toplumdan dışlanmış kayıt dışı çalışanlar, kadınlar, engelliler, göçmenler, azınlıklar, çocuklar, yaşlılar ve gençlerin, ekonomik şoklar, sağlık şokları, doğal afetler, iklim değişikliği ve endüstri kazaları, çatışma ve iç karışıklıklar gibi durumlarda, kısıtlı yetkinlikleri ve toplumdaki konumları ve yaşam döngüsündeki hassas dönemleri neticesinde yetersiz toplumsal bütünlük, tepkisizlik devlet kurumları ve zayıf yönetişim sonuçları ortaya çıkmaktadır (Ortakavak, 2019: 39).

Risklerle beraber incelenen kırılganlık (vulnerability), risk unsuru olan durumlarda, hasar görebilirlik ya da zarar görebilirlik ve kimi zaman da savunmasızlık ile ilişkili olarak tanımlanmaktadır. "Toplumdaki bazı gruplar, kadınlar, yaşlılar, çocuklar, mülteciler, engelli gruplar, kırılganlık açısından tanımlandığında başkalarının yardımına ihtiyaç duyma bakımından risk karşısında daha fazla hasar görebilir durumda kabul edilebilmektedir. Ayrıca, kırılganlığı belirleyen faktörler arasında demografik özellikler, coğrafi konumlar, cinsiyet farklılıkları, sağlık ve sosyal güvenlik sistemleri ve toplumsal gerilimler tanımlanabilir" (Ortakavak vd., 2019: 38). Toplumların özgün yapıları, coğrafi konumları, gelișmişlik düzeyleri gibi parametreler, hem kırılganlığı yüksek düzeye taşımakta, hem de bununla ilişkili olarak dirençliliğin azalmasına ve ani travmalar ve afetler gibi büyük değişim dönemlerinde normale dönebilme süresini uzatabilmekte ve kimi zaman da değişime uyum sağlayabilmeyi imkânsız kılabilmektedir. Toplumsal açıdan tüm bu ilişkisellik dikkate alındığında, sosyal kırılganlık endekslerinin belirlenerek, risk hesaplamaları yapılması ve sonrasında da afet sonrası iyileştirme planlamalarının, kırılgan grupların öncelikli olarak dikkate alınarak oluşturulması, ülkeler düzeyinde önemli bir gereklilik olarak kabul edilmelidir. Bu bağlamda, devletlerin, risk yönetimi konusunda politikalar geliștirmenin gerekliliğine daha fazla önem verdiği ve riskin değerlendirilmesi ve yönetilmesi aşamalarında sosyal kırılganlık verilerini dikkate almayı gerekli görüldüğü gözlemlenmektedir (Ortakavak, vd., 2019: 38).

Hem politik hem de toplumsal açıdan değerlendirildiğinde, dirençlilik kavramının kırılganlık süreçleriyle ilişkisinin önemi daha net hale gelebilmektedir. Dirençliliğin kırılganlık endeksleriyle beraber daha ölçülebilir hale gelmesi de, hem kavramın daha net anlaşılmasına hem de dirençlilik ve özelinde kırılganlık çalışmalarıyla değişme dönemlerinin daha kontrollü olarak 
yönetilebilmesine olanak vermektedir. Özellikle bölgesel farklıllklar ekseninde, dirençlilik ve kırılganlık ilişkisi daha belirgin hale gelmektedir ve bu nedenle de, devletler düzeyinde tekli risk planlamaları yerine, farklı coğrafi, ekonomik ve toplumsal yapılar dikkate alınmaya başlanmasının ve kırılganlık ve dirençliliğin düzeyinin belirlenmesinin risk öncesi büyük önem taşıdığı görünür hale gelmektedir.

\section{Sonuç ve Öneriler}

Sosyal bilimlerin en yaygın çalışma konularından biri olarak değişme kavramı, toplumların tarihsel süreç içerisinde geçirdikleri farklılaşmalara odaklanırken gerek evrimci, gerek tarihsel, gerekse ilerlemeci olarak kavramsallaştırılan birçok kuramın temel araştırma konusunu oluşturmuştur. Sosyolojinin temel sorunsallarından biri olarak değişme, hemen her dönemde, önemli bir alanı oluştururken, değişmenin farklı dinamikleri disiplinler arası çalışmalarda da önem kazanmaya başlamaktadır. Comte sosyolojisinin temel derdi olan değişme kavramı, her ne kadar yirmi birinci yüzyıl toplumsal hayatından farklı olsa da, metodolojik olarak toplumu anlamanın yollarını inşa etmesi açısından büyük önem taşımaktadır. Durkheim, Marx, Weber, Parsons, Althusser, Lukacs ve Habermas gibi sosyal kuramcılar da değişmeye farklı yaklaşımlar geliştirerek, kimi zaman büyük kimi zaman orta ölçekli kuramlar ekseninde değişmenin ve sonrasında toplumsal düzeni inşanın ya da yeni toplumsal yapıların inşasının çözümlemesini yapmayı amaçlamışlardır. Bu bağlamda, değişmenin teknoloji ve ekonomiye bağlı olarak kazandığı yeni boyutlar, değiş̧menin farklı alanlarda ele alınmasını gerekli kılmaktadır. Artan insan etkileşimleri ve büyük bir ivme kazanan insan, sermaye ve bilgi hareketliliği ekseninde, sosyolojinin ve tüm bilimlerin klasik kuramların üzerine inşa edeceği yeni alanlar açılmaktadır.

Yirmi birinci yüzyıl, her ne kadar insanlık tarihinin teknolojik düzeyde büyük bir hızla değiştiği bir dönem olsa da, birçok toplum tarafından, bu dönem içerisinde özellikle doğal afetler açısından birçok farklı yıkım ve değişim süreçleri deneyimlenmiştir. Afet çalışmalarında doğal afetler ve özellikle depremler, sel ve kasırgalar üzerine yoğunlaşma daha dikkat çekici düzeydedir. Bu çalışmalarda, özellikle afet yönetimi alanında afet öncesi risklerin belirlenmesi, hazırlık aşamaları, afet sonrası müdahale ve iyileştirme dönemlerine dair faaliyetler ağırlık kazanmaktadır. Özellikle afetlerin fen ve mühendislik bilimlerinde sıklıkla çalışılan fiziksel boyutunun yanında, afetlere dair toplumsal çözümlemeler yapabilmek adına disiplinler arası çalışmalar da yaygınlaşmaktadır. Bu bağlamda, afet ve sonrasında müdahale ile ilişkili bir kavram olan ve etimolojik olarak esneklik kavramından, sosyal dayanıklılığa ve afet, travma sonrası iyileşme kapasitesine evrilen dirençlilik kavramı sosyolojik anlamda da değişmeyle ilişkili olarak ele alınabilmektedir. Afet sonrası gerçekleșen, ani ve çoğu zaman büyük fiziksel ve toplumsal yıkımlar dikkate alındığında, sosyolojinin temel sorunsallarından bir diğeri olan, düzene ne zaman yeniden kavuşulabileceği sorusu önem kazanmaktadır. Yaşanılan büyük yıkımlar sonrası müdahale süreçlerinde, toplumların dirençlilik kapasitesi ve değişme arasında ilişkisel bir yakınlık olduğu dikkat çekmektedir. Bu nedenle, sosyoloji ve değişme yazınında dirençlilik ve ona etki eden göstergeler üzerine yoğunlaşılması önem taşımaktadır. Ayrıca, Parsons'un Genel Sistem Kuramında yer aldığı gibi toplumlarda sistemlerin sürekli düzene geri dönecek şekilde işlev göstermesi ön kabulüyle, düzenin yeniden inşası da sosyolojik bir odak noktasını oluşturmaktadır. Bu bağlamda, doğa afetler sonrasında dirençlilik ve değişmenin ilişkiselliğinde, toplumsalın yeniden yeniden üretiminin, önemli bir sosyolojik sorunsal olması da bu çalışmanın önemli vurgularından biridir.

Afet sonrası iyileşme süreçlerinde uyum ve düzene yeniden uyum sağlamanın bir ölçütü olarak dirençlilik aynı zamanda kırılganlık kavramıyla da yakın iliş̧i içerisinde ele alınmalıdır. Bireylerin ya da toplumların tehlikelere dair duyarllıkları ve hassasiyetlerini belirleyen, ekonomik, sosyal ve çevresel faktörler, kırılganlığı ve dirençliliği etkileyen ölçütler olarak önem kazanmaktadır. Dolayısıyla, önlenmesi kaçınılmaz olan doğal afetler için, hazırlık aşamalarında, riskler belirlenirken, farklı toplumsal yapılar ve farklı sistemler ekseninde, kırılganlık düzeylerinin de tespit edilmesi, afet sonrası iyileşme yani normale ve düzene geri dönme aşamalarında en önemli belirleyiciler olacaktır. 
$\mathrm{Bu}$ çalışma kapsamında ele alınan temel tartışmalar ekseninde, değişmenin afet sonrası boyutları ele alınırken, dirençlilik yani afet sonrasında iyileşme ve uyum gösterebilme becerisinin ve sosyal açıdan kırılgan kabul edilebilecek grupların belirlenmesi, hem akademik açıdan, hem de karar alıcı ve uygulayıcı kurumlar açısından önem arz etmektedir. Klasik değişme kuramları bağlamında, toplumların, her zaman düzene ve uyuma yöneldikleri ön kabulüyle, düzenin sağlanmasında dirençlilik gibi farklı kavramların da sosyal bilimler açısından daha sık ele alınması gerekli görülmektedir. Bu şekilde, toplumsal yapıların kırılgan unsurlarının da aynı ilişkisellik içerisinde incelenmesi, büyük travmalar sonrası değişimle daha kolay başa çıkabilmeyi ve "düzene" yeniden dönebilmeyi kolaylaştıracaktır.

Hakem Değerlendirmesi: Dış bağımsız.

Finansal Destek: Yazar bu çalışma için finansal destek almadığını beyan etmiştir.

Peer-review: Externally peer-reviewed.

Grant Support: The author received no financial support for the research, authorship, and/or publication of this article.

\section{Kaynakça/ References}

Akşit, B. (1985). Köy, kasaba ve kentlerde toplumsal değiş̧me. Ankara: Turhan Kitabevi.

Akyel, R. (2007). Afet yönetim sistemi: Türk afet yönetiminde karş̧laşllan sorunların tespit ve çözümüne ilişskin bir araştırma. (Yayınlanmamış Doktora Tezi), Çukurova Üniversitesi, Sosyal Bilimler Enstitüsü, Adana.

Alexander, D. E. (2013). Resilience and disaster risk reduction: En etymological journey. Natural Hazards and Earth System Sciences, 13, 2707-2716.

Althusser, L. (1971). Lenin and philosophy and ither essays. Monthly Revies Press: New York.

Bates, F.L. ve W.G. Peacock. (1987). Disasters and Social Change. R.R. Dynes, B. De Marchi ve C. Pelanda (Ed.). The Sociology of Disasters (ss. 291-330) içinde. Milan, Italya: Franco Angeli Press.

Bock, K. (2002). İlerleme, gelişme ve evrim kuramları. T. Bottomore ve R. Nisbet, (Ed.) Sosyolojik Çözümlemenin Tarihi içinde, Ankara: Ayraç Yayınevi.

Börekçi, D.Y. ve Gerçek, M. (2018). "Resilience" kavramının sosyal bilimlerde Türkçe kullanımları bağlamında değerlendirilmesi. Pamukkale Üniversitesi Sosyal Bilimler Enstitüsü Dergisi, 30.

Can, İ. (2020). Giriş niyetine: Afet sosyolojisine alan açma çabası. İ. Can (Ed.). Afet sosyolojisi içinde (ss. 15-36). İstanbul: Çizgi Kitabevi.

Childe, G. (1951). Man makes himself. New York: Mentor Books.

Childe, G. (1964). What happened in history. Baltimore: Penguin Books.

Comte, A. (1822). Plan of the scientific operations necessary for reorganizing society. System of positive polity. (J. H. Bridges Çev.). Londra: Longmans, Green and Co.

Dynes, R. (1988). Cross- cultural international research: Sociology and disaster. International Journal of Mass Emergencies and Disasters, 6 (2), 101-129.

Erol, M. (2008). Düzen, kaos ve değişme. Hacettepe Türkiyat Araștırmaları Dergisi, 125-154.

Freyer, H. (2015). Sosyoloji kuramları tarihi. İstanbul: Doğu Batı Yayınları. 
Freyer, H. (2015). Sosyoloji kuramları tarihi (M. Rami Ayas, Çev.). Ankara: Doğu Batı Yayınları.

Gökçen, A. (2020). Afet kavramı ve başlıca afet türleri. İ. Can (Ed.). Afet Sosyolojisi içinde (ss. 285300). İstanbul: Çizgi Kitabevi.

Gramsci, A. (1975). Felsefe ve politika sorunları (A. Cemgil, Çev.). İstanbul: Payel Yayınevi.

Guessous, M. (1967). A general critique of equilibrium theory. Moore ve Cook (Ed.). Readings on social change. Englewood Cliffs: Prentice Hall.

Lengnick-Hall, C. A., Beck, T. E., ve Lengnick-Hall, M. L. (2011). Developing a capacity for organizational resilience through strategic human resource management. Human Resource Management Review, 21(3), 243-255.

Lewis, D. (2020). Rezilyans kavramı: Ortaya çıkışı, evrimi ve uygulanabilirliği bir kentsel rezilyans kılavuzu, Yerel Yönetişim ve Göç Dizisi-6, SLK Interntional AB, Ankara: Uzerler Matbaacılık.

Lukacs, G. (1971). History and class consciousness. Cambridge, Massachusets: The MIT Press.

Koç, A.S. (2017). Olağanüstü durumlar, iletişim ve habercilik yaklaşımları. TRT Akademi, 2(3), 6-47.

Kongar, E. (1995). Toplumsal değiş̧me kuramları ve Türkiye gerçeği. İstanbul: Remzi Kitabevi.

Kundak, S (2017). Dirençliliğin temelleri. Dirençlilik Dergisi, 1(1), 55-69.

Marcuse, H. (1941). Reason and Revolution. London: Routledge and Kegan Paul.

Moore, Jr. B. (1997) Social origins of dictatorship and democracy: Lord and peasentin the making of the modern world. London: Penguin.

Oktik, N. (2006). Yapı ve değişme araştırmalarında yeni arayışlar. Felsefe ve sosyal bilimler sempozyumu bildiri kitabı. İstanbul: Vadi Yayınları.

Ortakavak, Z., Uslu, A. ve Korkmaz, E. (2019). Sosyal kırılganlık indeksinin CBS ile haritalanması: İzmir İli örneklemi. Dirençlilik Dergisi, 3 (1), 37-53.

Özer, Y. E. (2018). Risk azaltma yaklaşımı çerçevesinde dirençli kentler. Bursa: Ekin Basın Yayın Dağııtım.

Politzer, G. (1969). Felsefenin başlangıç ilkeleri (Cem Eroğul, Çev.). Ankara: Sol Yayınları.

Ponomarov, S.Y. \& Holcomb, M. (2009). Understanding the concept of supply chain resilience. The International Journal of Logistics Management, 20 (1), 124-143.

Ritzer, G. (2010). Klasik sosyoloji kuramları. Ankara: De Ki Sosyoloji.

Smith, P (2005). Kültürel kuram. İstanbul: Babil Yayınları.

Smith, L. C. ve Frankenberger, T.R. (2018). Does resilience capacity reduce the negative impact of shocks on household food security? Evidence from the 2014 floods in Northern Bangladesh, World Development, 102, 358-376. doi: 10.1016/j.worlddev.2017.07.003.

Sorokin, P. A. (1942). Man and society in Calamity: Effetcs of war, revolution, famine, pestilence upon human mind, behavior, social organization and cultural life. Virginia: William Byrd Press.

Steward, J. H. (1959). Theory of culture change. Urbana: University of Illinois Press.

Timmerman, P. (1981). "Vulnerability resilience and collapse of society". A Review of Models and Possible Climatic Applications. Toronto, Canada: Institute for Environmental Studies, University of Toronto.

Quarantinelli, E.L. (1972) When disaster strikes (It isn't much like what you've heard and heard about), Psychology Today 5, 66-70. 
Yaman M. ve Çakır, E. (2020). Farklı boyutlarıyla afet yönetimi. Ankara: Nobel Yayınevi.

Yılmaz Börekçi, D. (2014). Feminen ve maskülen dağıtık liderlik dağıtık liderlik aracıllğıyla örgütsel rezilyans. 2. Örgütsel Davranış Kongresi'nde sunulan bildiri, Kayseri.

Varol, N. ve Kırıkkaya, E. B. (2017). Afetler karşısında toplum dirençliliği, Dirençlilik Dergisi, 1 (1), 19. doi: 10.32569/resilience.344784

Weber, M. (1947). The theory of social and economic organisation. (A.M. Henderson ve T. Parsons Çev.). Londra: Oxford University Press.

White, L. (1949). The science of culture. New York: Grove Press. 